\title{
UV-A-induced expression of GroEL in the UV-A-resistant marine cyanobacterium Oscillatoria sp. NKBG 091600
}

\author{
Akira Yamazawa, Haruko Takeyama, Daisuke Takeda \\ and Tadashi Matsunaga \\ Author for correspondence: Tadashi Matsunaga. Tel: +8142388 7020. Fax: +81423857713. \\ e-mail : tmatsuna@cc.tuat.ac.jp
}

Department of

Biotechnology, Tokyo University of Agriculture \&

Technology, 2-24-16

Nakacho, Koganei, Tokyo

184-8588, Japan

\begin{abstract}
The authors have examined the response to UV-A irradiation of the UV-Aresistant marine cyanobacterium Oscillatoria sp. NKBG 091600, which produces the UV-A-absorbing compound biopterin glucoside. The expression of a $60 \mathrm{kDa}$ protein was markedly induced at $\mathbf{5 0 0} \mathrm{min}$ after UV-A irradiation. This protein was identified by $\mathbf{N}$-terminal amino acid sequence analysis as GroEL. Northern blot analysis demonstrated that GroEL synthesis was controlled by UV-A at the transcriptional level. A CIRCE element and a putative SOS consensus sequence were found upstream of the groESL operon, overlapping two putative promoter sequences. Primer extension analysis revealed that groESL transcription in UV-A-induced cells starts from the proximal promoter overlapped by the SOS consensus sequence. This indicates that an SOS response regulation is instrumental in UV-A-induced GroEL expression of Oscillatoria sp. NKBG 091600. Furthermore, this UV-A-inducible GroEL may function to upregulate biopterin glucoside biosynthesis, thereby allowing growth under UV-A irradiation.
\end{abstract}

Keywords: stress response, UV-A resistance, biopterin glucoside, GroEL, marine cyanobacterium Oscillatoria sp.

\section{INTRODUCTION}

UV-A irradiation causes oxidative stress in several eukaryotes and prokaryotes (Bose et al., 1990; Cadet et al., 1993; Hu \& Tappel, 1992; Parat et al., 1995; Savoure et al., 1996; Yamada et al., 1996). UVabsorbants have been found in several cyanobacteria (Matsunaga et al., 1993; Scherer et al., 1988; Shibata, 1969), and the biosynthesis of these pigments was found to be UV-responsive (Ehling-Schulz et al., 1997; Matsunaga et al., 1993; Scherer et al., 1988). We have investigated the physiological response of a UV-Aresistant marine cyanobacterium, Oscillatoria sp. NKBG 091600, to UV-A irradiation (Matsunaga et al., 1993). A UV-A-absorbing pigment was isolated and identified as biopterin glucoside, which is chemically related to pterin pigments of butterfly wings. UV-A was found to be a potent elicitor of biopterin glucoside

Abbreviations: CIRCE, controlling inverted repeat of chaperone expression; $\mathbf{I R}$, inverted repeat.

The GenBank accession number for the sequence reported in this paper is AF054630. biosynthesis. UV-A may cause significant damage to cyanobacteria by inhibiting energy acquisition by the photosynthetic reaction system (Hirosawa \& Miyachi, 1982, 1983; Sinha et al., 1995). Wachi et al. (1995) investigated the effect of UV-A intensity on cell growth, biosynthesis of biopterin glucoside and photosynthetic activity in a UV-A-resistant Oscillatoria sp., and observed that the loss of photosynthetic activity following exposure to UV-A was attenuated by prior UVA exposure. These observations support the hypothesis that biosynthesis of UV-absorbing pigments functions as an adaptive strategy for protection against the adverse effects of UV irradiation. To further elucidate the biochemical basis of cyanobacterial UV-A resistance, we have examined the effect of UV-A irradiation on protein synthesis in Oscillatoria sp. NKBG 091600.

\section{METHODS}

Cyanobacterial strains and culture conditions. The marine Oscillatoria sp. NKBG 091600 and the freshwater Synechococcus sp. PCC 7942 were used in this study. NKBG 091600 and PCC 7942 were cultured in BG-11 medium (Allen \& Stanier, 1968), supplemented with and without $3 \% \mathrm{NaCl}$, 
respectively, under cool-white fluorescent light $\left(500 \mu \mathrm{W} \mathrm{cm} \mathrm{cm}^{-2}\right)$ at $28^{\circ} \mathrm{C}$. Initial cell density was $10^{6}$ cells $\mathrm{ml}^{-1}$. Growth was monitored by measuring $\mathrm{OD}_{750}$.

UV-A treatment of cyanobacterial cells. Cells grown to midexponential phase with $500 \mu \mathrm{W} \mathrm{cm}{ }^{-2}$ of cool-white fluorescent light irradiation were harvested and then suspended in fresh medium (final cell density adjusted to $\mathrm{OD}_{750} 0 \cdot 8$ ). A disposable Petri dish (Iwaki; $8.5 \mathrm{~mm}$ diameter) containing $20 \mathrm{ml}$ of the cell suspension was irradiated with a combination of coolwhite fluorescent light $\left(500 \mu \mathrm{W} \mathrm{cm}{ }^{-2}\right)$ and UV-A light $(900 \mu \mathrm{W}$ $\mathrm{cm}^{-2}$ ) from a UV-A lamp (Cosmo Bio; CSL-30A). Cells were harvested by centrifugation $(3500 \mathrm{~g}$ for $10 \mathrm{~min}$ at room temperature) at $100 \mathrm{~min}$ intervals over the course of $15 \mathrm{~h}$, frozen using liquid nitrogen, and stored at $-80^{\circ} \mathrm{C}$ until analysed.

Preparation of the water-soluble fraction from cyanobacterial cells and SDSPAGE analysis. Pelleted cells stored at $-80^{\circ} \mathrm{C}$ were thawed quickly, and suspended in disruption buffer containing $25 \mu \mathrm{l}$ glycerol, $1 \mu \mathrm{l} 10 \%$ SDS, $0 \cdot 1 \mu \mathrm{l} \beta$ mercaptoethanol and $5 \mu \mathrm{l} 200 \mathrm{mM}$ phenylmethanesulfonyl fluoride, followed by the addition of $300 \mu$ l buffer $(10 \mathrm{mM}$ Tris/ $\mathrm{HCl}, 1 \mathrm{mM}$ EDTA, $\mathrm{pH} 7 \cdot 5)$. The cells were ruptured by sonication for $15 \mathrm{~min}$ at $4{ }^{\circ} \mathrm{C}$, then centrifuged $(25000 \mathrm{~g}$, $30 \min , 4^{\circ} \mathrm{C}$ ).

The supernatant was denatured for $10 \mathrm{~min}$ at $100^{\circ} \mathrm{C}$ in $40 \mu \mathrm{l}$ $0.0625 \mathrm{M}$ Tris $/ \mathrm{HCl}, \mathrm{pH} 6.8,1.25 \%$ SDS, $25 \%$ glycerol and $1 \cdot 25 \%$ 2-mercaptoethanol. The denatured solution was centrifuged for $10 \mathrm{~min}$ and a sample of the supernatant $(20 \mu \mathrm{l}$ containing $100 \mathrm{ng}$ protein) was analysed by SDS-PAGE on a $1.0 \mathrm{~mm}$ thick slab gel $(10 \%$ acrylamide separating gel, $4 \%$ acrylamide stacking gel) using the buffer system of Laemmli (1970). The gel was stained with Coomassie brilliant blue. Protein concentration in the supernatant was determined by spectrophotometry at $205 \mathrm{~nm}$ (Scopes, 1974).

Protein purification and $\mathbf{N}$-terminal amino acid sequencing. The target band in the stained gel was excised, and the protein was extracted by electroelution. The solution of the target protein was concentrated, and spotted on a PVDF membrane (Millipore; Immobilon-Psq). The $\mathrm{N}$-terminal amino acid sequence was determined using a polypeptide sequencer (Shimadzu; PPSQ-10).

DNA sequencing of groESL and Northern analysis. Genomic DNA was extracted from cyanobacterial cells by standard procedures (Porter, 1988). Two primers for amplifying groESL from Oscillatoria sp. NKBG 091600 were designed based on conserved DNA regions in groESL sequences from Synechococcus sp. PCC 7942 and Synechocystis sp. PCC 6803 (ESF1, GAGTTCGGGAAMCCRYACT ; ELR1, TCTTCGATYTGGCGACGGATTTG). The PCR product was cloned into pCRII vector (Invitrogen), and sequenced using an automatic DNA sequencing machine (Shimadzu; DSQ-1000L). A computer software package, LASERGENE (DNASTAR), was used for DNA sequence analysis.

Northern analysis was conducted using total RNA extracted from harvested cells according to the method of Chomczynski (1987). Digoxigenin (DIG)-labelled DNA probe for Northern hybridization was prepared by PCR amplification of a part of the groEL gene of Oscillatoria sp. NKBG 091600. Hybridization was performed using a DIG DNA Detection Kit (Boehringer Mannheim).

Primer extension analysis. Potential transcriptional start sites were identified by primer extension with RNA isolated from UV-A-irradiated cells. DNA-free total RNA $(10 \mu \mathrm{g})$ and FITClabelled primer (AGGGATACTGCTGCCATAGGAATACTCTCC: $40 \mathrm{pmol}$ ) were dissolved in $40 \mu \mathrm{l}$ buffer $[10 \mathrm{mM}$
Tris/ $\mathrm{HCl}(\mathrm{pH} \mathrm{8.3)}, 50 \mathrm{mM} \mathrm{KCl}, 5 \mathrm{mM} \mathrm{MgCl}, 1 \mathrm{mM}$ each dNTP, 40 U human placenta ribonuclease inhibitor (Takara)] containing $10 \mathrm{U}$ AMV (avian myeloblastosis virus) reverse transcriptase (Life Sciences). Extension reaction was carried out at $55^{\circ} \mathrm{C}$ for $1 \mathrm{~h}$, following incubation at $99^{\circ} \mathrm{C}$ for $10 \mathrm{~min}$ to inactivate reverse transcriptase. The synthesized cDNA was ethanol-precipitated, washed with $70 \%$ ethanol and dissolved in $1 \mu \mathrm{l}$ nuclease-free water. After adding $1 \mu \mathrm{l}$ formamide loading dye (Thermo sequence fluorescent labelled primer cycle sequence kit; Amersham), the reaction mixture was heat-denatured at $95^{\circ} \mathrm{C}$ for $5 \mathrm{~min}$ and analysed by the DSQ$1000 \mathrm{~L}$ automatic DNA sequencing machine in parallel with a dideoxynucleotide sequencing reaction primed with the same oligonucleotide.

\section{RESULTS}

\section{Identification of a UV-A-inducible protein in Oscillatoria sp. NKBG 091600}

Fig. 1 shows the SDS-PAGE pattern of water-soluble proteins extracted from the UV-A-resistant Oscillatoria sp. NKBG 091600 and the UV-A-sensitive Synechococcus sp. PCC 7942 (Hirosawa \& Miyachi, 1983) after $15 \mathrm{~h}$ UV-A irradiation. Induction of a $60 \mathrm{kDa}$ protein was observed in NKBG 091600 . In contrast, induction of a corresponding SDS-PAGE band was not observed in the UV-A-sensitive PCC 7942.

Twenty-five $\mathrm{N}$-terminal amino acid residues (without the first two amino acids) of the UV-A-responsive $60 \mathrm{kDa}$ protein were determined. Homology searching using protein databases indicated that the $60 \mathrm{kDa} \mathrm{UV}$ A-responsive protein sequence displayed similarity to cyanobacterial GroEL chaperonins $196 \%$ identity to Synechococcus sp. PCC 6301 and PCC 7942, and $84 \%$ to Synechocystis sp. PCC 6803). The $60 \mathrm{kDa}$ protein cross-

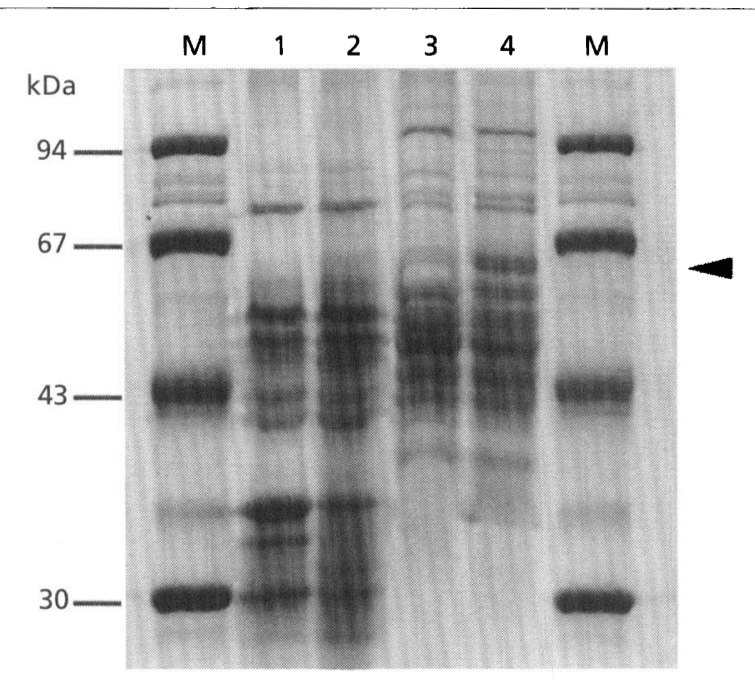

Fig. 1. SDS-PAGE of water-soluble proteins extracted from Synechococcus sp. PCC 7942 (lanes 1 and 2) and Oscillatoria sp. NKBG 091600 (lanes 3 and 4) irradiated with UV-A. Lanes 1 and 3 , cells were irradiated with a cool-white fluorescent light; lanes 2 and 4, cells were irradiated with a combination of coolwhite fluorescent light and UV-A light for $15 \mathrm{~h}$. M, size markers. The induced $60 \mathrm{kDa}$ protein in lane 4 is indicated by an arrowhead. 
The sequence of upstream region

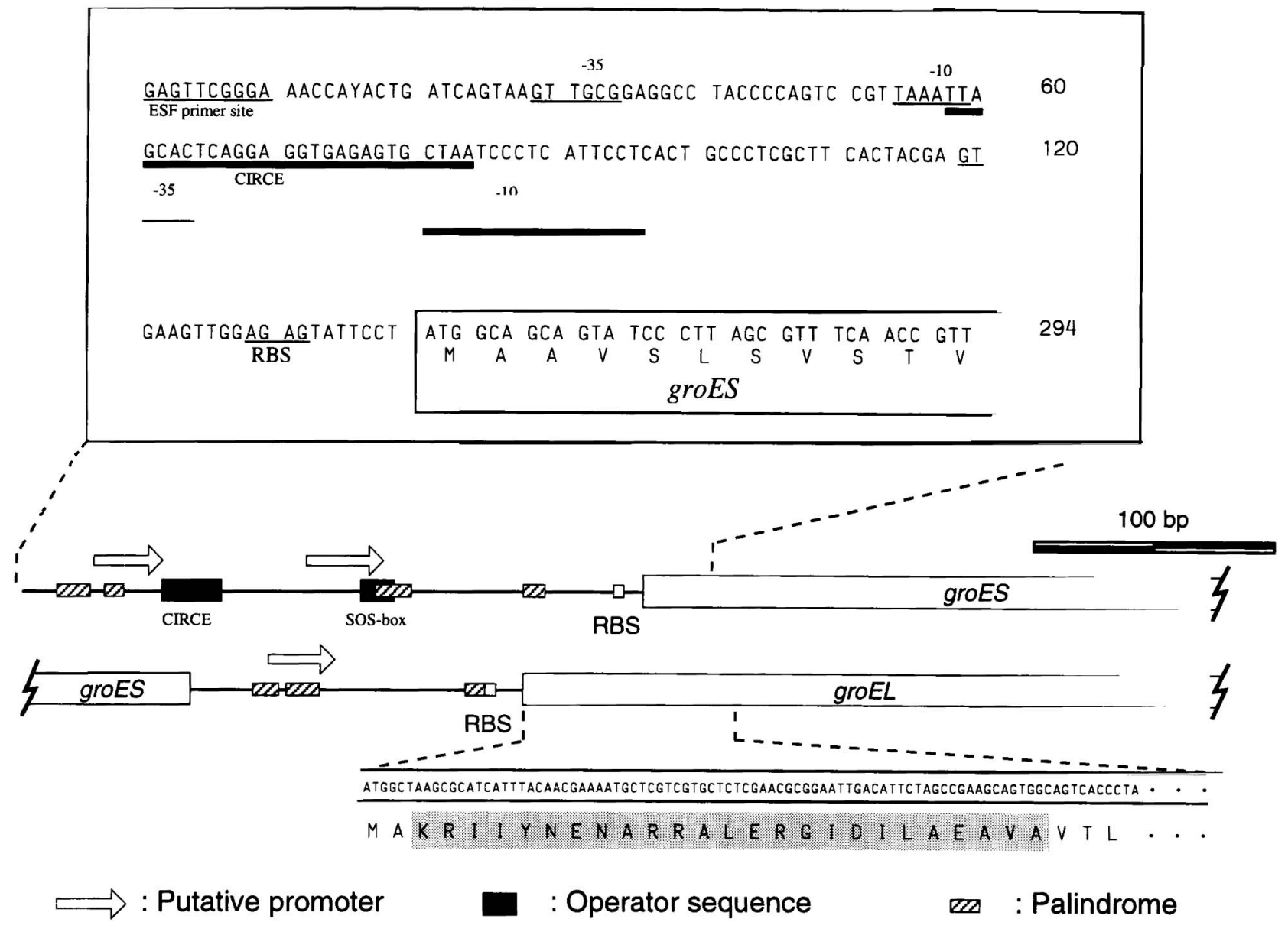

Fig. 2. The groESL operon from Oscillatoria sp. NKBG 091600. Two putative -35 and -10 sequences, and the putative RBS sequence, within the upstream region of groES are underlined. The CIRCE and a putative SOS box are marked with bold underlining. The amino acid sequence with shaded background shows the deduced GroEL amino acid sequence matching that obtained from $\mathrm{N}$-terminal sequencing of the $60 \mathrm{kDa}$ protein.

reacted with antibody raised against GroEL of Synechococcus sp. PCC 7942 (data not shown).

\section{Cloning and sequencing of the groESL operon of Oscillatoria sp. NKBG 091600}

The groESL operon was amplified from genomic DNA of Oscillatoria sp. NKBG 091600 using PCR primers designed from conserved sequences in groESL of $S y n$ echococius sp. PCC 7942 and Synechocystis sp. PCC 6803. The DNA sequence of the amplified fragment $(1.7 \mathrm{kbp})$ shows that the amplified fragment includes groES with $260 \mathrm{bp}$ of upstream region and $1059 \mathrm{bp}$ of the groEl. $5^{\prime}$ region (Fig. 2; GenBank AF054630). Part of the deduced GroEL amino acid sequence matched that obtained from $\mathrm{N}$-terminal sequencing of the $60 \mathrm{kDa}$ protein (Fig. 2, bottom). DNA sequence analysis revealed that groES and partial groEL of NKBG 091600 showed high similarity with the corresponding sequence from Synechococcus sp. PCC $7942(74 \%$ identity at the nucleotide level). In contrast, the upstream region of
groES, and the region between groES and groEL, from NKBG 091600 exhibited poor similarity to corresponding sequences from Synechococcus sp. PCC 7942. A perfect inverted repeat (IR) of $9 \mathrm{bp}$ (TTAGCACTC- $\mathrm{N}_{9^{-}}$ GAGTGCTAA) is located 175 bp upstream of the groES translation initiation codon. This IR corresponds to the CIRCE (controlling inverted repeat of chaperone expression) element observed upstream of the groESL operon of Bacillus subtilis (Mogk et al., 1997). The CIRCE in the other cyanobacterial strains Synechococcus PCC 7942 and Synechocystis PCC 6803, is located $55 \mathrm{bp}$ and $57 \mathrm{bp}$ upstream of the translation initiation codon, respectively, i.e. closer to the translation initiation codon than the CIRCE of NKBG 091600. Putative -35 and -10 hexamers were identified according to similarity with the -10 and -35 consensus region of the groESL operon of Synechococcus sp. PCC 7942 (-35, GTTGCC; - 10, TACATT) (Webb et al., 1990). The sequence CTGCTCAATCAACCAG (nt 141 to 156 ; the common motif is underlined), which resembles the SOS box consensus sequence of Escher- 


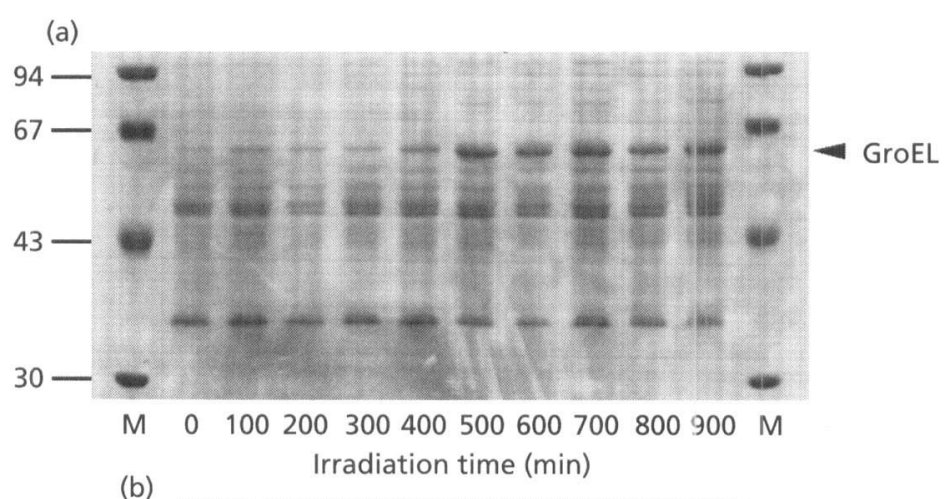

(b)

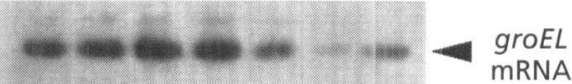

0100200300400500600700800900
groEL

RNA
Fig. 3. Protein profile of water-soluble fraction (a) and Northern blot of groEL transcripts (b) in Oscillatoria sp. NKBG 091600 during 900 min UV-A irradiation. M, molecular mass markers ( $k D a)$.

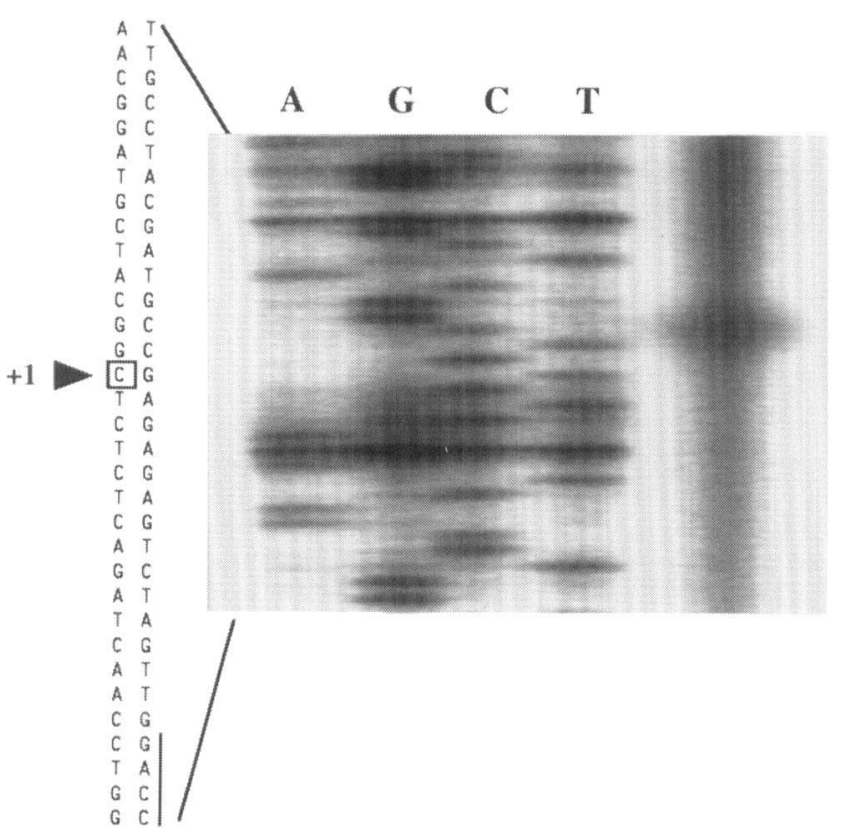

Fig. 4. The putative groESL operon transcriptional start site determined by primer extension of RNA from cells irradiated with UV-A. An oligonucleotide complementary to groESL mRNA was used for both reverse transcriptase primer extension (farright lane) and nucleotide sequencing. The DNA sequence of the putative SOS box is side-lined. +1 , putative transcriptional start site.

ichia coli (Walker 1984), is located 104 bp upstream of the translation initiation codon within a second putative promoter sequence $(-35$ and -10$)$.

\section{Time course of groEL gene expression and mRNA synthesis during UV-A irradiation}

The induction profile of GroEL was determined by SDSPAGE (Fig. 3a). Induction of GroEL began at $400 \mathrm{~min}$ and reached a maximum at $500 \mathrm{~min}$ after the start of
UV-A irradiation. This induction correlated with that of a UV-A-absorbing pigment, biopterin glucoside, which rapidly increases at approximately $9 \mathrm{~h}$ after UV-A irradiation (Matsunaga et al., 1993).

Northern blot analysis using a groEL probe (from nt 875 to nt 1767) demonstrated an accumulation of groEL mRNA at $300 \mathrm{~min}$ after UV-A irradiation, which persisted over $300 \mathrm{~min}$ (Fig. 3b). This result confirmed that the UV-A-dependent expression of GroEL is controlled at the transcriptional level.

\section{Determination of the transcription initiation site}

We determined the transcription start site of the groESL operon by primer extension analysis with an oligonucleotide, complementary to positions nt 247 to nt 276 , on RNA isolated from a culture irradiated by UV-A. A single transcription start site was identified $89 \mathrm{bp}$ upstream from the groES translation initiation codon and $15 \mathrm{bp}$ downstream from the putative SOS box sequence (Fig. 4).

\section{DISCUSSION}

Various environmental stresses are known to induce GroEL, including heat, acid, radicals and near-UV (Hartke et al., 1997; Hendrix, 1979; Kilstrup et al., 1997; Mecsas et al., 1991; Segal \& Ron, 1996; Sherman \& Goldberg, 1992). Krueger \& Walker (1984) showed that UV light and nalidixic acid activated the SOS response and the expression of GroEL by different regulation mechanisms in E. coli. Shibata et al. (1991) also demonstrated by using ${ }^{14} \mathrm{C}$ labelling that near-UV irradiation $(295-390 \mathrm{~nm})$ induced synthesis of 16 proteins in Synechococcus sp. PCC 7942, several of which were also induced by heat shock, and five of which were induced by treatment with methyl viologen (a source of free oxygen radicals). In the present study, UV-A strongly induced transcription and synthesis of GroEL 
in the UV-A-resistant Oscillatoria sp. NKBG 091600 but not in the UV-A sensitive Synechococcus sp. PCC 7942.

Two putative promoters and two operator sequences were found upstream of groES in NKBG 091600. A $9 \mathrm{bp}$ IR corresponds to CIRCE elements, which have been shown to play an important role in the heat induction of the groESL operons of $B$. subtilis and other bacterial species including cyanobacteria (Hecker et al., 1996; Mogk et al., 1997). Compared to previously characterized CIRCEs, the CIRCE of NKBG 091600 is located further upstream of the predicted transcriptional start site of the groESL operon. A putative promoter overlapping the CIRCE motif was apparently not used during UV-A-induced transcription of the operon. However, a transcript starting from a promoter located more proximal to the translation start site was identified by primer extension analysis of mRNA extracted from UV-A-induced cells. The promoter of this transcript overlaps with an SOS consensus sequence. As near-UV light is known to generate $\mathrm{O}_{2}^{-}$and $\mathrm{H}_{2} \mathrm{O}_{2}$ (Sammartano et al., 1985; Shibata et al., 1991; Tyrrell, 1985), it is plausible to assume that the SOS box is involved in the control of GroEL expression.

Hirosawa \& Miyachi (1982) reported that cyanobacterial cells exposed to UV-A contained less chlorophyll and phycocyanin, and more carotenoid, than nonirradiated cells. We have also observed a decrease in the content of photosynthetic pigments, especially phycocyanin, in Oscillatoria sp. NKBG 091600 after UV-A irradiation; however, a recovery of phycocyanin content correlating with GroEL and biopterin glucoside induction was observed (data not shown). The temporal relationship of GroEL induction in NKBG 091600 to biopterin glucoside biosynthesis and the reconstitution of photosynthetic pigments suggests that this UV-Ainducible GroEL might function to upregulate biopterin glucoside biosynthesis, thereby allowing growth under UV-A irradiation.

\section{ACKNOWLEDGEMENTS}

We thank Dr Elliot J. Adler, of Department of Biology, University of California at San Diego, for help in preparation of this manuscript. This work was funded in part by Grant in Aid for Scientific Research no. 10450306 from the Ministry of Education, Science, Sports and Culture of Japan.

\section{REFERENCES}

Allen, M. M. \& Stanier, R. Y. (1968). Selective isolation of bluegreen algae from water and soil. J Gen Microbiol 51, 203-209.

Borbély, G., Surányi, G., Korcz, A. \& Pálfi, Z. (1985). Effect of heat shock on protein synthesis in the cyanobacterium Synechococcus sp. strain PCC 6301. J Bacteriol 161, 1125-1130.

Bose, B., Agarwal, S. \& Chatterjee, S. N. (1990). Membrane lipid peroxidation by UV-A: mechanism and implications. Biotechnol Appl Biochem 12, 557-561.

Cadet, J., Incardona, M. F., Odin, F. \& 7 other authors (1993). Measurement of oxidative base damage to DNA by using HPLC-
${ }^{32} \mathrm{P}$-postlabelling and GC/MS-selective ion monitoring assays. In Postlabelling Methods for Detection of DNA Adducts (IARC Scientific Publication 124), pp. 271-276. Edited by D. H. Phillipes, M. Castegnaro \& H. Bartsch.

Chomczynski, P. (1987). Single-step RNA isolation from cultured cells or tissues. In Current Protocols in Molecular Biology, pp. 421-422. Edited by F. M. Ausubel and others. New York: Wiley.

Ehling-Schulz, M., Bilger, W. \& Scherer, S. (1997). UV-B-induced synthesis of photoprotective pigments and extracellular polysaccharides in the terrestrial cyanobacterium Nostoc commune.J Bacteriol 179, 1940-1945.

Hartke, A., Frere, J., Boutibonnes, P. \& Auffray, Y. (1997). Differential induction of the chaperonin GroEL and the cochaperonin GroES by heat, acid, and UV-irradiation in Lactococcus lactis subsp. lactis. Curr Microbiol 34, 23-26.

Hecker, M., Schumann, W. \& Völker, U. (1996). Heat-shock and general stress response in Bacillus subtilis. Mol Microbiol 19, $417-428$.

Hendrix, R. W. (1979). Purification and properties of GroESL, a host protein involved in bacteriophage assembly. J Mol Biol 129, 375-392.

Hirosawa, T. \& Miyachi, S. (1982). Effects of long-wavelength ultraviolet (UV-A) radiation on the growth of Anacystis nidulans. Plant Sci Lett 28, 291-298.

Hirosawa, T. \& Miyachi, S. (1983). Inactivation of Hill reaction by long-wavelength ultraviolet radiation (UV-A) and its photoreactivation by visible light in the cyanobacterium, Anacystis nidulans. Arch Microbiol 135, 98-102.

Hu, M. L. \& Tappel, A. L. (1992). Potentiation of oxidative damage to proteins by ultraviolet-A and protection by antioxidants. Photochem Photobiol 56, 357-363.

Kilstrup, M., Jacobsen, S., Hammer, K. \& Vogensen, F. K. (1997). Induction of heat shock proteins, DnaK, GroEL, and GroES by salt stress in Lactococcus lactis. Appl Environ Microbiol 63, 1826-1837.

Krueger, J. H. \& Walker, G. C. (1984). groEL and $d n a K$ of Escherichia coli are induced by UV irradiation and nalidixic acid in an btpR $R^{+}$-dependent fashion. Proc Natl Acad Sci USA 81, 1499-1503.

Laemmli, U. K. (1970). Cleavage of structural proteins during the assembly of the head of bacteriophage T4. Nature 227, 680-685.

Matsunaga, T., Burgess, J. G., Yamada, N., Komatsu, K., Yoshida, S. \& Wachi, Y. (1993). An ultraviolet (UV-A) absorbing biopterin glucoside from the marine planktonic cyanobacterium Oscillatoria sp. Appl Microbiol Biotechnol 39, 250-253.

Mecsas, J., Cowing, D. W. \& Gross, C. A. (1991). Development of RNA polymerase-promoter contacts during open complex formation. J Mol Biol 220, 585-597.

Mogk, A., Homuth, G., Scholz, C., Kim, L., Schmid, F. X. \& Schumann, W. (1997). The GroESL chaperonin machine is a major modulator of the CIRCE heat shock regulon of Bacillus subtilis. EMBO J 16, 4579-4590.

Parat, M. O., Richard, M. J., Leccia, M. T., Amblard, P., Favier, A. \& Beani, J. C. (1995). Does manganese protect cultured human skin fibroblasts against oxidative injury by UV-A, dithranol and hydrogen peroxide? Free Radical Res 23, 339-351.

Porter, D. R. (1988). DNA transformation. Methods Enzymol 167, 703-712.

Sammartano, L. J. \& Tuveson, R. W. (1985). Hydrogen peroxide induced resistance to broad-spectrum near-ultraviolet light $(300$ 
$400 \mathrm{~nm}$ ) inactivation in Escherichia coli. Photochem Photobiol 41, 367-370.

Savoure, N., Maudet, M., Nicol, M., Pelissier, M. A., Albrecht, R., Briand, G. \& Combre, A. (1996). Modulation of ultraviolet lightinduced oxidative stress in mice skin related to dietary vitamin $A$ and selenium intake. Int J Vitamin Nutr Res 66, 306-315.

Scherer, S., Chen, T. W. \& Böger, P. (1988). A new UV-A/B protecting pigment in the terrestrial cyanobacterium Nostoc commune. Plant Physiol 88, 1055-1057.

Scopes, R. K. (1974). Measurement of protein by spectrophotometry at $205 \mathrm{~nm}$. Anal Biochem 59, 277-282.

Segal, G. \& Ron, E. Z. (1996). Heat shock activation of the groESL operon of Agrobacterium tumefaciens and the regulatory roles of the inverted repeat. J Bacteriol 178, 3634-3640.

Sherman, M. Y. \& Goldberg, A. L. (1992). Heat shock in Escherichia coli alters the protein-binding properties of the chaperonin GroEL by inducing its phosphorylation. Nature 357, 167-169.

Shibata, H., Baba, K. \& Ochiai, H. (1991). Near-UV irradiation induces shock proteins in Anacystis nidulans R-2; possible role of active oxygen. Plant Cell Physiol 32, 771-776.

Shibata, K. (1969). Pigment and a UV-absorbing substance in corals and blue-green alga living in the Great Barrier Reef. Plant Cell Pbysiol 10, 325-335.

Sinha, R. P., Lebert, M., Kumar, A., Kumar, H. D. \& Häder, D.-P. (1995). Spectroscopic and biochemical analysis of UV effects on phycobiliproteins of Anabaena sp. and Nostoc carmium. Bot Acta 108, 87-92.

Tyrrell, R. M. (1985). A common pathway for protection of bacteria against damage by solar UV-A (334 nm, $365 \mathrm{~nm})$ and an oxidising agent $\left(\mathrm{H}_{2} \mathrm{O}_{2}\right)$. Mutat Res 145, 129-136.

Wachi, Y., Burgess, J. G., Iwamoto, K., Yamada, N., Nakamura, N. \& Matsunaga, T. (1995). Effect of ultraviolet-A (UV-A) light on growth, photosynthetic activity and production of biopterin glucoside by the marine UV-A resistant cyanobacterium Oscillatoria sp. Biochim Biophys Acta 1244, 165-168.

Walker, G. C. (1984). Mutagenesis and inducible response to deoxyribonucleic acid damage in Escherichia coli. Microbiol Rev 48, 60-93.

Webb, R., Reddy, K. J. \& Sherman, L. A. (1990). Regulation and sequence of the Synechococcus sp. strain PCC 7942 groESL operon, encoding a cyanobacterial chaperonin. J Bacteriol 172, 5079-5088.

Yamada, K., Ono, T. \& Nishioka, H. (1996). Effect of $\mathrm{NaN}_{3}$ on oxygen-dependent lethality of UV-A in Escherichia coli mutants lacking active oxygen-defence and DNA-repair systems. J Radiat Res 37, 29-37.

Received 9 November 1998; revised 7 January 1999; accepted 8 January 1999. 